DOI: doi.org/10.21009/IJLECR.071.05

Received: 5 April 2021

Revised: 22 June 2021

Accepted: 25 June 2021

Published: 30 June 2021

\title{
THE NEEDS OF TECHNOLOGY TRANSFORMATION IN FRENCH LITERATURE LEARNING
}

\author{
Evi Rosyani Dewi ${ }^{1, a)}$, Ninuk Lustyantie ${ }^{1, b)}$, Fathurrahman Nur Isnan ${ }^{1, \mathrm{c})}$ \\ Universitas Negeri Jakarta, Indonesia ${ }^{1)}$ \\ evird@unj.ac.id ${ }^{\text {a) }}$,ninuk.lustyantie@unj.ac.id ${ }^{\text {b) }}$,Fathur_Anan@hotmail.com ${ }^{\text {c) }}$
}

\begin{abstract}
The development of technology has a real impact on the development of education. Education must be able to adapt to be better, one of which is learning French literature. This study aims to determine learners' perceptions of the need for technology implementation in French literature learning. This study used a survey method with a qualitative descriptive approach. The findings show that from 90 respondents, 37.9\% were strongly agreed, 56.6\% were agreed, $5.0 \%$ were neutral, $0.1 \%$ were disagreed, and $0.3 \%$ were strongly disagree with the need for technology implementation in French literature teaching and learning activities. Based on these findings, the implementation of technology is a must and even a necessity in learning French literature.
\end{abstract}

Keywords: Blended Learning; Distance Learning; French Literature; Technology.

The development of information and communication technology is currently, rapidly developed, so it is entering a new era, namely the era of the fourth industrial revolution or what is also known as the era of disruption. This rapid technological development forces every human to adapt to be able to face and follow the developments in information and communication technology in this era. The rapid development of this can be indicated by the many innovations and inventions in the world of technology, and their massive use in various fields of human activities. This development has also changed the way humans doing their activities. The existence of technology has also changed human work from conventional to online, digital, and virtual (Jin, Wen, \& Gough, 2010).

On the other hand, the world is currently facing the COVID 19 pandemic, which forces us to change our daily behavior. "New Normal" represents changes in human behavior, not only in the workplace but also in our society (Berwick, 2020). The new system that was adapting to this new habit can be seen in various domains, including the education domain which was fully engaged in distance learning activities during the pandemic.

The presence of the pandemic has indirectly stimulated the development of a system to be able to switch from conventional methods to fully technology-based systems quickly. In this case, universities are one of the institutions that are required to evolve rapidly. Provision of technologybased facilities and infrastructure is a must, which also develops into a virtual facility or infrastructure. As a resource, digitizing all the learning activities needs is the main focus in the teaching's success and learning process in this new normal (Budiman, 2017; Parvez, 2011).

Not free from the influence of technological developments, literature learning within the scope of higher education must also begin to transform in response to the demands of the 21 st era. 
Several studies have tried to adapt the concept of technology-based learning. Blended learning is a popular learning method used to balance the technology implementation in the learning process with the offline class method. Hughes, $\mathrm{Lu}$, and $\mathrm{Xu}$ (2019) tried to create Chinese literature learning in two types of Mandarin simultaneously. Even though it is well known for the difficulty of the Chinese language, Blended Learning is proven to create effective literature learning. The provision of virtual facilities during learning makes it easier for learners to explore learning material, either through the facilities provided by the teacher or through their exploration via the internet as Blended Learning is implemented.

On the other hand, Koszalka and Ntloedibe-Kuswan (2010) have conducted research related to the development of literature on technological developments that affect the learning process. According to them, the role of portable technology such as smartphones has contributed significantly to the development of digital literature. Then led to increased reading interest and the development of learning methods by implementing technology as the era of disruption was in progress. The urgency related to the use of technology in literacy education is also important to help the learning process and support learning outcomes. As Nurdyansyah and Widodo (2015) have found, information and technology can also give birth to new education features. Multimedia-based learning systems can present subject matter that is more interesting, varied, and deliver the teaching object easier.

With the various implementations of technology in literature learning, this study focuses on how students' perceptions of the need for technology implementation in French literature learning activities.

\section{Learning Foundation}

Halliday (2007) argues that in carrying out literature learning, three main foundations are needed which are then referred to as "Registers". The three main foundations are Field, Tenor, and Mode. The field focuses on the identity of a text of learning materials. The field is realized as a general linguistic description relating to content, context, or ideas. The tenor focuses on the relationship between the text and the author's character in a text. Moreover, this foundation is focused on the relationship between literary texts and their creators. Moreover, the last, the mode is a tool of how text is conveyed to readers. In the context of literary learning, Mode is a tool for learners in learning text, especially literature learning to provide material to learners.

The mode in learning focuses on what methods and media are suitable for use during teaching and learning activities. Mode is the most important part of the learning transformation process because this foundation is directly affected by technological developments. In this era, technological development is a major issue (Budiman, 2017; Lin \& Hwang, 2019). All teaching and learning activities must be able to adapt to the progress of information media that is developing rapidly and massively. Conventional classrooms are no longer providing adequacy in the teaching and learning process. Internet-based information media has become a new tool for supporting teaching and learning activities.

The need for renewable methods and media is a major requirement in the teaching and learning process, especially for learners because they are the main actors in the learning process. Therefore, in this study, the needs of learners are the main focus to be able to find out the needs of learners, especially students of French literature students, in facing the digital era. Moreover, the enactment of distance learning strengthens this demand as an impact of the COVID-19 pandemic. This then became our focuses to create a literature learning system that is able and capable of adapting to technological advances. 


\section{METHOD}

This study uses a survey method. The survey was conducted using a quantitative questionnaire with a qualitative descriptive approach. Researchers conducted a survey using an open questionnaire platform through Google Form using ten questions. After obtaining the data through the questionnaire, the researcher analyzed it through the response graph data. The data was developed through qualitative descriptive analysis. The subject of the survey which also the sources of data are the second and third year of French Department students in Universitas Negeri Jakarta who are taking Littérature Française I courses.

\section{RESULTS AND DISCUSSION}

As a first step in carrying out research, we try to determine student needs related to the implementation of technology in literacy learning. The target respondents are students who are currently taking the Littérature Française I course at the French Department, Universitas Negeri Jakarta. This needs analysis is carried out through a questionnaire mechanism by arranging points that become urgent in the transformation of the literary class from a conventional class into a modern class. This questionnaire was created by describing the competencies needed by students in learning literature. The competency referred is not only the learning method but also the media used. It is not limited to the type of media, but also the ability of the media in realizing the appropriate learning for students. Therefore, we tried to make 10 indicators that were allegedly able to answer students' needs for learning French literature through renewable technology. The ten points are as follows:

1. Future-proof learning method

2. Adaptive learning method

3. Flexible learning method

4. Distance learning capability/availability

5. Fun learning method

6. The use of most recent technology as learning media

7. Internet integrity for learning media

8. Audio-visual capability for learning media

9. Interactive learning media

10. The use of all-around interactive learning media

Based on the points above, we created a detailed statement which used as a questionnaire that contained students' perceptions of the implementation of technology in literature learning. The following is a description of the indicator points of student needs:

1. The French literature learning method used must keep up with the times.

2. The method used in learning French literature must be adaptive to technological developments.

3. The method used in learning French literature must use two or more methods to create flexible literature learning.

4. The method used in learning French literature should make it easier for students to be able to learn from anywhere (distance learning).

5. The method used in learning French literature is a fun method for students to support the learning process.

6. The media used in French literature learning must use the latest technology-based media.

7. The media used in French literature learning must be integrated through the internet.

8. The media used in French literature learning must be based on audio-visual media.

9. The media used in French literature learning must be utilizing interactive media. 
10. The use of technology-based multimedia with an audio-visual form can support the French literature learning process.

These statements are then compiled into a questionnaire table regarding the Likert questionnaire system (Allen \& Seaman, 2007), which has five choices in response to a statement. The five options consist of strongly agree, agree, neutral, disagree, and strongly disagree. After compiling the table format, the questionnaire data are distributed to 90 students through Google Form. After the questionnaire was distributed and responded to by the students, the results of the responses were as follows.

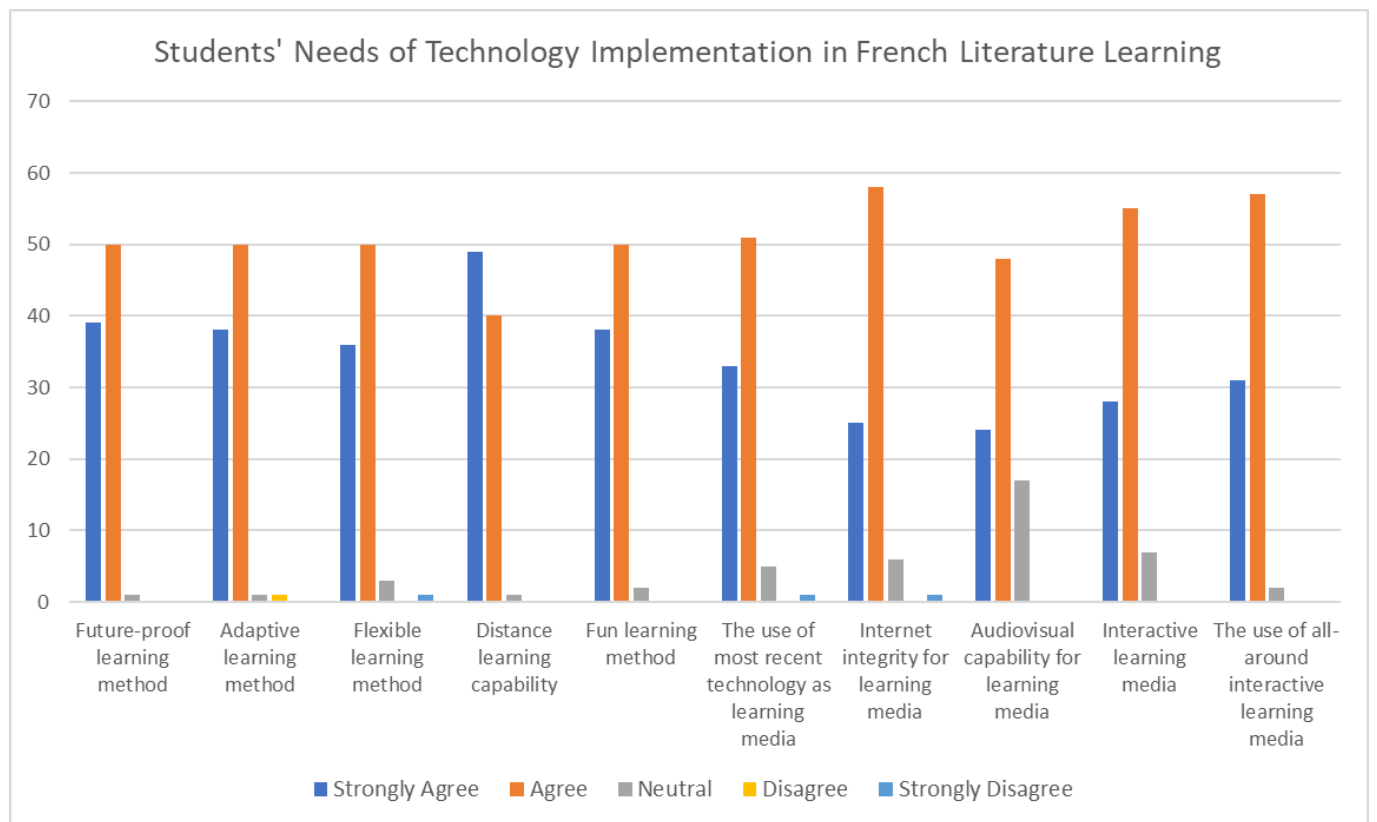

Figures 1. Students' Needs of Technology Implementation in French Literature Learning Response Graph.

The first statement is the student's response to the French literature learning method. The method adopted must meet the needs of students. The survey results stated that from 90 respondents, $43.3 \%$ were strongly agreed, $55.6 \%$ were agreed, and $1.1 \%$ were neutral regarding future-proof French literature learning methods and the use of methods that can keep up with the times. Based on this data, students generally agree that the French literature learning method in the Littérature Française I course must keep up with current learning developments so that teaching and learning activities can run effectively and efficiently. Of course, this future-proof method is not limited to being used in the long term but is also available to be updated in the teaching and learning process (Naidu \& Roberts, 2018).

Furthermore, the second statement is also focused on learning methods. The survey results stated that from 90 respondents, $42.2 \%$ were strongly agreed, 55.6\% were agreed, $1.1 \%$ were neutral, and $1.1 \%$ were disagreed with the French literature learning method which is adapted to the development and use of technology. Based on this data, students generally agree that the French literature learning method in the Littérature Française I course must be adaptive to current technological developments so it could be facilitated the learning process and also gain benefits from the technology used. In addition, to taking advantage of the convenience offered by renewable technology, adaptive learning methods also allow teaching and learning activities to adapt to the demands of education which are continuously updated every year (Shaykina \& Minin, 2018). Adaptive literary learning methods not only provide flexibility to students but can also have accordance with the times. 
Then on the next statement, this is also the students' response to the French literature learning method. The survey results stated that from 90 respondents, $40.0 \%$ were strongly agreed, $55.6 \%$ were agreed, $3.3 \%$ were neutral, and $1.1 \%$ were strongly disagreed regarding the use of French literature learning methods in the form of combining two or more methods. Based on this data, students generally agreed that the French literature learning method in the Littérature Française I course must use two or more methods to support an effective and flexible learning process. Flexibility in using the method is one of the answers to student boredom with the use of monotonous learning methods (Zhang, Lou, Zhang, \& Zhang, 2019). The use of two or more methods allows the teaching and learning process to be more varied.

Furthermore, on the fourth statement, this is also a students' response to the French literature learning method. The survey results showed that from 90 respondents, $54.4 \%$ were strongly agreed, 44.4\% were agreed, and $1.1 \%$ were neutral regarding flexible French literature learning methods. The flexibility that is promoted is not only in the use of teaching media or learning methods, the place of study and study time is also a major concern. Based on this data, students generally agree that the French literature learning method in the Littérature Française I course should make it easy for students to learn from anywhere (Distance Learning). The implementation of flexible teaching and learning activities is one of the needs of today's students (Jin et al., 2010). The presence of the coronavirus forces teaching and learning activities to be held outside of the school area or educational institutions such as campuses. Advanced technology can provide learning activities to be carried out more flexibly at a time and place that can be discussed with students (DarlingHammond \& Hyler, 2020).

Then on the next statement, the fifth statement is also the students' perception of the French literature learning method. The survey results stated that from 90 respondents, $42.2 \%$ were strongly agreed, 55.6\% were agreed, and 2.2\% were neutral regarding the use of fun literature learning methods. Based on these data, students generally agree that the learning methods used during teaching and learning activities in the Littérature Française I course must be fun for students to be able to support the learning process. Fun is not only based on interesting process but also the concept of learning that is easy to understand (Annisa, Saragih, \& Mursid, 2019)

In the sixth statement, this is a students' response to French literature learning media. The survey results stated that from 90 respondents, $36.7 \%$ were strongly agreed, $56.7 \%$ were agreed, $5.6 \%$ were neutral, and $1.1 \%$ were strongly disagreed with the use of media in the latest technologybased French literature learning. Based on this data, students generally agreed that the learning media used during French literature learning in the Littérature Française I course must be in the form of the use of the latest technology. Students as the main actors in teaching and learning activities, of course, understand more about technology, especially with the technology literacy skills of students nowadays that no need be doubted (Chung \& Ackerman, 2015). Students' skills in using technology can be utilized in learning so that students can easily understand learning material.

Then on the next statement, the seventh statement is also a students' response to French literature learning media. The survey results stated that from 90 respondents $27.8 \%$ were strongly agreed, $64.4 \%$ agreed, $6.7 \%$ were neutral, and $1.1 \%$ were strongly disagreed with the use of media integrated with the internet. Based on this data, students generally agree that the learning media used during French literature learning in the Littérature Française I course must be internet-based as a learning tool. The availability of the internet which is abundant at this time must be used as a means of supporting the learning process. It is not only easy as a means of communication but also information. Students, of course, are aware that the internet's contribution to teaching and learning activities is very large, especially in finding information related to French literature (NesbittAhmed, 2017). With the increasing digitization of information, literature can easily be obtained with access via the internet 
Furthermore, on the next statement, this is also the students' response to French literature learning media. The survey results stated that from 90 respondents $27.0 \%$ were strongly agreed, $53.9 \%$ were agreed, and $19.1 \%$ were neutral towards the use of audio-visual media in learning French literature. Based on these data, students generally agreed that the learning media used during French literature learning in the Littérature Française I course must be in the form of audio-visual media. Audio-visuals in literature-based learning are quite important to be able to understand content in French literature. French theatre and poetry, for example, are literary works that are very thick with audio nuances. It is not only beautiful in terms of literature, but also the way it carries it through music or spectacle. It is not limited to the two literary works, novels and short stories are also included in the audio-visual concept. Currently, written works have provided audio to be able to read and listen at the same time. This type of writing was later called the audible book (Wiazowski, 2009). France who has many forms of written work as literature is of course starting to adapt the concept of audible books.

On the next statement, this is also a student response to French literature learning media. The survey results stated that from 90 respondents $31.1 \%$ were strongly agreed, $61.1 \%$ were agreed, and $7.8 \%$ were neutral towards the use of interactive media in learning French literature. Based on this data, students generally agreed that the learning media used during French literature learning in the Littérature Française I course is an interactive learning medium that allows students to interact with learning material during teaching and learning activities. Interactive learning media is not only limited to interactions between lecturers and students, but also between students and the learning media used. Advances in technology allow learning media to be used as interactive media (Cairncross \& Mannion, 2001). Various interactive media options are freely available on the internet such as interactive learning videos, quizzes, books and even games. Some of the interactive media used as teaching media in higher education are interactive quizzes and flipbooks (Mora, Mérida, \& Eixarch, 2011; Wibowo \& Pratiwi, 2018). Besides being able to compress the material into one teaching medium, the availability of interactive media can make teaching and learning activities more varied and fun.

On the last statement, the tenth statement is the students' perception of French literature learning media. The survey results stated that from respondents $34.4 \%$ were strongly agreed, $63.3 \%$ were agreed, and $2.2 \%$ were neutral towards the use of literary learning media through audio-visualbased technology during teaching and learning activities. Based on this data, students generally agreed that the use of literary learning media through audio-visual-based technology can support the learning process of French literature. Students agreed that changes are needed by adapting technological developments to support teaching and learning activities (Deed, Lesko, \& Lovejoy, 2014).

Based on the data from the questionnaire results above, it can be concluded that from 90 students, $37.9 \%$ of them were strongly agreed, $56.6 \%$ of them were agreed, $5.0 \%$ of them were neutral, $0.1 \%$ of them were disagreed, and $0.3 \%$ were strongly disagreed on the implementation of technology in all teaching and learning activities, from methods to media.

The first to the fifth statement is a statement that gives an idea of how the students' desire for learning French literature takes place. The majority of respondents agreed. They agreed that learning French literature should be technology adaptive, flexible, and support the concept of distance learning. Then, the sixth to tenth statements is a point that provides an overview of the use of technological media in learning French literature. The majority of respondents agreed that the media used was the latest technology, interesting, interactive, and supported the concept of distance learning. For more details, the student's response to an agreement on the implementation and development of French literature teaching and learning activities through renewable technology can be seen in the following diagram. 


\section{Average Student Perceptions of the Need of Technology Implementation in French Literature Learning}

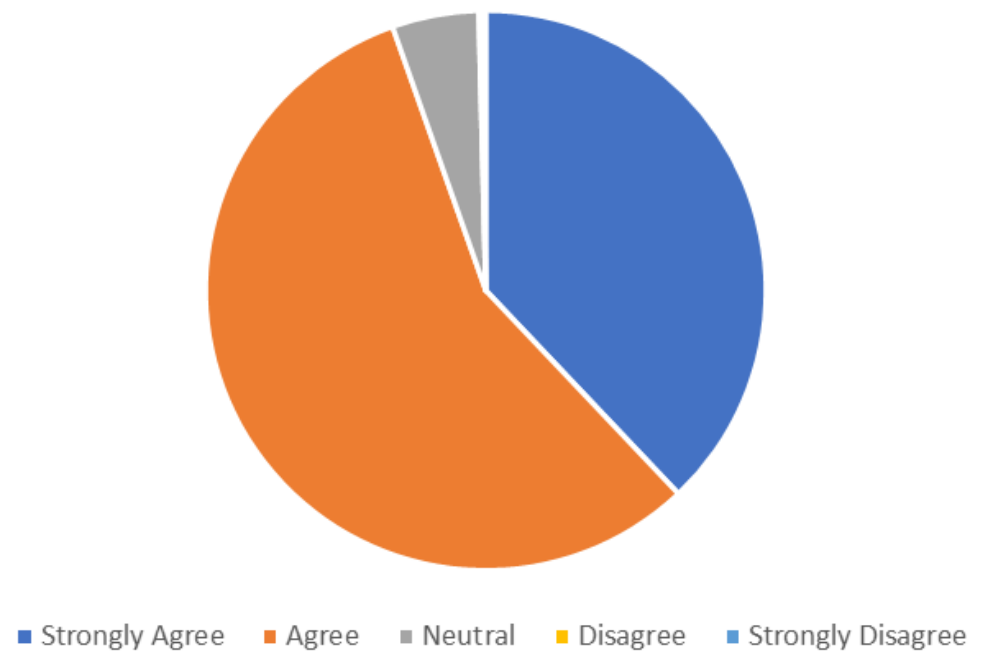

Figures 2. Graph of Average Student Perception of Technology Implementation in Literature Learning.

After seeing the responses to these students, learning in the 21st era turned out to require significant changes to the use of technology during the teaching and learning process. Learners as active users of renewable technology want the implementation of technology in a learning process, so they can create learning which is suited for them. The latest internet-based technology can be an attractive option. For example, social media such as Whatsapp, Facebook, or Twitter can be used as learning media (Bosch, 2009; Jovanovic \& Leeuwen, 2018; Tay \& Allen, 2011). The various features presented not only support the interaction system between users but also can share documents and files which of course are needed in teaching and learning activities (Gonick, 2015). In addition to its various features, this social media can be implemented easily because students are already familiar with the technology. The existence of features such as audio-visual-based files like a video on timelines can be an appropriate media to become a place for interactive discussions between teachers and learners (Elbanna, C. Thanos, \& M. Papadakis, 2014).

Along with the development of the times, various software, applications, and internet-based sites can be integrated into a learning system for any educational institution, including the higher education system (Stickler, 2008). This is very possible considering that the current situation in all forms of institutions normally has one or two integrated social networks or social media as verified accounts. Therefore, the implementation of technology that is familiar to learners in learning French literature is not impossible, it would make learning activities easier to applies.

On the other hand, the world is currently experiencing a COVID-19 pandemic. This condition forces every human being to change their way of doing activities (Bryson \& Andres, 2020). To avoiding crowds and preventing the spread of the virus during the pandemic, every community is obliged to stay at home. This then changes the habit of doing activities from working in the workplace to become work from home. Educational-themed activities also get affected. Learning during the pandemic carries the concept of distance learning (Darling-Hammond \& Hyler, 2020). In this learning, the learning system is no longer held face-to-face between lecturers and students but is transformed into a virtual face-to-face network through an internet connection using a variety of applications. The existence of social media in teaching and learning activities like this is very important. Currently, social media applications have provided various features that support 
teaching and learning activities with a complete classroom requirement, such as video calls, file sharing, and discussion forums (Bosch, 2009; Solihati \& Mulyono, 2017). Therefore, the implementation of renewable technology in learning French literature is very important. The needs of virtual classrooms, up to learning materials, can all be made available through the most recent technology. It is not only limited to convenience but also its attractiveness. Through audio-visualbased interactive media, of course, it can provide a new atmosphere in teaching and learning activities (Jin et al., 2010). This of course will have a good impact on the teaching and learning process.

Although internet-based technology such as social media makes it easy to integrate learning into cyberspace, the learning methods used must also support the learning concept. As a form of transformation of conventional learning, blended learning is an appropriate choice (Míguez-Álvarez, Crespo, Arce, Cuevas, \& Regueiro, 2020). The combination of face-to-face learning with virtual face-to-face learning makes it easier for learners to explore and associate all their knowledge of knowledge into learning French literature. The implementation of virtual face-to-face as distance learning activities is carried out as a forum for learners to be able to freely explore the knowledge that is not obtained in face-to-face learning which can then be applied to their thinking results.

\section{CONCLUSION}

Nowadays, technological developments are inevitable. All aspects of life have implemented various technologies to facilitate human work. Education also could not escape from the effects of technological developments. Education as an educational system is currently trying to adapt to technological sources, especially the development of the online education system. Online education is no longer relying on conventional methods, but it has turned into a modern system that makes it easier, more attractive, and more flexible. Therefore, as one of the many fields of education, we try to assess the need for technology implementation in learning French literature.

In this study, we further examine what kind of implementation the learners want or how the learners' perceptions, if technology is implemented directly in teaching and learning activities. Sticking to the theory of the foundations of learning by Halliday (2007) implementing technology in the learning process can be done on the foundation of Mode. The mode in practice is a method and media used in teaching and learning activities that are always suitable to technological innovation.

Through this foundation, we try to see the needs of students related to the implementation of technology in learning French literature. Through a questionnaire developed based on mode foundation, we find that the majority of respondents agree that literary learning needs to implement renewable technology. Students' needs for the renewal of the learning process focus on interesting lectures through internet-based media, flexible learning concepts, and distance learning. Finally, students agreed that the latest learning concepts needed to be developed because according to them, these things would make the learning process of French literature easier.

On the other hand, the role and implementation of technology in learning is very important. As a facility, technology allows learning to be more flexible. The concept of blended learning or distance learning is the highlight that learning must adapt to technology. Internet-based French literature learning allows learners to participate in learning activities more effectively. In addition, audio-visual technology is also needed by students in learning French literature because the concept is not only interesting but also easy to use. Audio-visual-based media is an implementation of technology for literature learning which will later be developed into teaching materials. 


\section{REFERENCES}

Allen, I. E., \& Seaman, C. A. (2007). Likert scales and data analyses. Quality Progress, 40(7), 6465.

Annisa, N., Saragih, A. H., \& Mursid, R. (2019). Pengembangan Media Pembelajaran Interaktif Pada Mata Pelajaran Bahasa Inggris. Jurnal Teknologi Informasi \& Komunikasi Dalam Pendidikan, 5(2), 210-221. https://doi.org/10.24114/jtikp.v5i2.12599

Berwick, D. M. (2020). Choices for the "New Normal.” JAMA, 323(21), 2125. https://doi.org/10.1001/jama.2020.6949

Bosch, T. E. (2009). Using online social networking for teaching and learning: Facebook use at the university of cape town. Communicatio. https://doi.org/10.1080/02500160903250648

Bryson, J. R., \& Andres, L. (2020). Covid-19 and rapid adoption and improvisation of online teaching: curating resources for extensive versus intensive online learning experiences. Journal of Geography in Higher Education, 1-16. https://doi.org/10.1080/03098265.2020.1807478

Budiman, H. (2017). Peran Teknologi Informasi Dan Komunikasi Dalam Pendidikan. AlTadzkiyyah: Jurnal Pendidikan Islam, 8(1), 31. https://doi.org/10.24042/atjpi.v8i1.2095

Cairncross, S., \& Mannion, M. (2001). Interactive multimedia and learning: Realizing the benefits. Innovations in Education and Teaching International, 38(2), 156-164. https://doi.org/10.1080/14703290110035428

Chung, C., \& Ackerman, D. (2015). Student Reactions to Classroom Management Technology: Learning Styles and Attitudes Toward Moodle. Journal of Education for Business. https://doi.org/10.1080/08832323.2015.1019818

Darling-Hammond, L., \& Hyler, M. E. (2020). Preparing educators for the time of COVID ... and beyond. European Journal of Teacher Education, 00(00), 1-9. https://doi.org/10.1080/02619768.2020.1816961

Deed, C., Lesko, T. M., \& Lovejoy, V. (2014). Teacher adaptation to personalized learning spaces. Teacher Development. https://doi.org/10.1080/13664530.2014.919345

Elbanna, S., C. Thanos, I., \& M. Papadakis, V. (2014). Understanding how the contextual variables influence political behaviour in strategic decision-making: A constructive replication. Journal of Strategy and Management. https://doi.org/10.1108/JSMA-02-2014-0013

Gonick, B. L. S. (2015). New Media and Learning in the 21st Century. (T.-B. Lin, V. Chen, \& C. S. Chai, Eds.), Educause Review. Singapore: Springer Singapore. https://doi.org/10.1007/978981-287-326-2

Halliday, M. A. . (2007). Language and Education. The collected Works of M.A.K. Halliday.

Hughes, N., Lo, L., \& Xu, S. (2019). Blended Chinese language learning design: an integrative review and synthesis of the literature. Language Learning Journal. https://doi.org/10.1080/09571736.2017.1280526

Jin, L., Wen, Z., \& Gough, N. (2010). Social virtual worlds for technology- enhanced learning on an augmented learning platform. Learning, Media and Technology, 35(2), 139-153. https://doi.org/10.1080/17439884.2010.494424

Jovanovic, D., \& Leeuwen, T. Van. (2018). Multimodal dialogue on social media, 0330. https://doi.org/10.1080/10350330.2018.1504732

Koszalka, T. A., \& Ntloedibe-Kuswani, G. S. (2010). Literature on the safe and disruptive learning potential of mobile technologies. Distance Education. https://doi.org/10.1080/01587919.2010.498082

Lin, H. C., \& Hwang, G. J. (2019). Research trends of flipped classroom studies for medical courses: a review of journal publications from 2008 to 2017 based on the technology-enhanced learning model. Interactive Learning Environments. https://doi.org/10.1080/10494820.2018.1467462 
Míguez-Álvarez, C., Crespo, B., Arce, E., Cuevas, M., \& Regueiro, A. (2020). Blending learning as an approach in teaching sustainability. Interactive Learning Environments. https://doi.org/10.1080/10494820.2020.1734623

Mora, Á., Mérida, E., \& Eixarch, R. (2011). Random learning units using WIRIS quizzes in moodle. International Journal of Mathematical Education in Science and Technology. https://doi.org/10.1080/0020739X.2011.583396

Naidu, S., \& Roberts, K. J. (2018). Future proofing higher education in the Pacific with open and flexible learning. Journal of Learning for Development, 5(3), 280-295.

Nesbitt-Ahmed, Z. (2017). Reclaiming African literature in the digital age: an exploration of online literary platforms. Critical African Studies, 9(3), 377-390. https://doi.org/10.1080/21681392.2017.1371618

Nurdyansyah; Widodo, A. (2015). Inovasi Teknologi Pembelajaran (1st ed.). Sidoarjo: Nizamia Learning Center.

Parvez, A. (2011). Development in Library Services with the Advent of ICT Based Productions and Services: A Continous Process. International Journal of Digital Library Services, 1(2), 1-8.

Shaykina, O. I., \& Minin, M. G. (2018). Adaptive internet technology as a tool for flipping the classroom to develop communicative foreign language skills. International Journal of Emerging Technologies in Learning. https://doi.org/10.3991/ijet.v13i07.8092

Solihati, N., \& Mulyono, H. (2017). A hybrid classroom instruction in Second Language Teacher Education (SLTE): A critical reflection of teacher educators. International Journal of Emerging Technologies in Learning. https://doi.org/10.3991/ijet.v12i05.6989

Stickler, U. (2008). Chatting, Chatten or Chattare: Using a Multilingual Workspace for Language and Culture Learning. International Journal of Emerging Technologies in Learning (IJET). https://doi.org/10.3991/ijet.v3i1.731

Tay, E., \& Allen, M. (2011). Designing social media into university learning: Technology of collaboration or collaboration for technology? Educational Media International. https://doi.org/10.1080/09523987.2011.607319

Wiazowski, J. (2009). Audible Books with Acoustic Illustrations. Journal of Special Education Technology, 24(4), 60.

Wibowo, E., \& Pratiwi, D. D. (2018). Pengembangan Bahan Ajar Menggunakan Aplikasi Kvisoft Flipbook Maker Materi Himpunan. Desimal: Jurnal Matematika. https://doi.org/10.24042/djm.v1i2.2279

Zhang, J., Lou, X., Zhang, H., \& Zhang, J. (2019). Modeling collective attention in online and flexible learning environments. Distance Education, 40(2), 278-301. https://doi.org/10.1080/01587919.2019.1600368 